Vol. 5, No. 1, 2021

UDK 336.77:330.3

JEL Classification Code: E32, E44, G21

\author{
L. Shkvarchuk' ${ }^{1}$, R. Slav'yuk ${ }^{2}$, \\ Lviv Polytechnic National University, \\ ${ }^{1}$ Department of Finance, \\ ${ }^{2}$ Department of Entrepreneurship and Environmental Examination of Goods \\ ORCID: ${ }^{1}$ 0000-0001-7241-3961, ${ }^{2}$ 0000-0002-0904-8970
}

\title{
PRIVATE DEBT AND ECONOMIC GROWTH: TRENDS AND CHARACTERISTICS FOR UKRAINE
}

http://doi.org/10.23939/semi2021.01.112

(C) Shkvarchuk L., Slav'yuk R., 2021

Purpose. The purpose of the article is to determine the effects on economic activity of a pure temporary change in private debt and the relationship between the debt multiplier and the level of economic growth in Ukraine.

Design/methodology/approach. In the article, the authors used the function of exponential growth for determining the $G D P$ sensibility to the debt movements. There are also using the Granger approach for determining the direction of the relation between private debt and GPD. Rather than testing whether private debt causes GDP, the Granger causality has tested whether private debt forecasts GDP. The authors provided the calculation in the direct and indirect methods. The model of the direct method was based on the assumption that the GDP growth in the current period depends on the dynamics of GDP and increase of private debt in the previous period. The model of indirect correlation was based on the assumption that the increase of the amounts of private debt depends on the former dynamics of $G D P$ and the amount of private debt accumulated in the previous period.

Findings. The hypothesis that the GDP sensibility to the private debt movements is individual for every economy is proven. The households' debt to GDP ratio and non-financial firms' debt to $G D P$ ratio for the conditions of economy of Ukraine is one of the lowest in Europe, which proves the low attractiveness of debt financing of the private sector growth. The authors show that elevated private debt sentiment in year $t+3$ is associated with a rising in economic activity in year $t$. Such conclusion is fair as for the sensitivity to the households' debt movements and so to the firms' debt movements. The increase in private debt causes the insufficient influence on the GDP increasing, so we cannot consider the debt market growth as a stimulator of the economy growth in Ukraine. The authors showed the existence of a relation between the GDP growth and increase of private debt only in indirect model. Private sector debt cycle more correlated with the business cycles: in the case of GDP growth the private debt rises also. But, the strength of influence of the GDP growth on the private debt growth is temperate: while the increase in the GDP by $1 \%$ in the medium predicts $0.055 \%$ subsequent private debt growth.

Practical implications. The debt-growth nexus has received renewed interest among academics and policy makers. The results of this research are of interest to the government in its way of economic reform and generating effective tools to overcome the economic downturn. Also, the findings can help the financial market regulators to realize the effective monetary policy.

Originality/value. This study represents a new evidence of relations between private debt and the real economy. In contrast to existing research the authors argued the reality of indirect impact of economical cycles to the private debt dynamic. But, the strength of influence of the GDP growth on 
the private debt growth is temperate. So it's wrong to consider the debt market development as a stimulator of the economic growth in Ukraine. In contrast to the developed countries in Ukraine the main part of private debt belongs to firms.

Key words: private debt; household debt to $G D P$ ratio; non-financial firms debt to GDP ratio; economic growth; GDP sensibility to the debt movements.

\section{Problem statement}

The debt is an important stimulator of economic growth, as far as it can provide the increase of consumption, industrial production, and the number of state expenditures. Thus, the mechanism of such stimulant impact appears only in certain conditions, which are particular for every country, depending on the phase of the economic cycle, peculiarities of financial market functioning, a characteristic feature of consumption and financial behaviour of households, etc. The attraction of debt into the economic turnover has double influence, which is caused by the existence of positive and negative peculiarities. The advantages of such attraction are associated with a consumption, investments, and production boom. The credit supply expansion can finance either an expansion in demand or an increase in the economy's productive capacity. So, V. Horin (2017) shows that at the one side household debt stimulates the development of the national economy, and at the other side it gives people the possibility to solve the problem of the financial recourses deficit for the appropriate fulfillment of their needs [6]. S. Handzyuk, Y. Vyshnyakova (2019) add, that giving loans to people influences the development of the national economy, in particular, helps to formulate the solvent demand, which makes the process of production realization easier, accelerates the process of profit generation and budget receipts [5]. E. Verner (2019) is sure, that key patterns in the data indicate that private debt booms largely boost demand instead of productive capacity [20]. J. Silva (2020) prove that debt of the private sector could have an impact on private gross added value and would necessarily assign future resources generated by the private sector to the payment of interests to the rest of the world [17].

At the same time, the attractiveness of credit resources increases the burden of expenditures on the economic agents, what together with the negative factors often is the reason for its insolvency and bankruptcy. M. Randveer, L. Uusküla and L. Kulu (2012) demonstrate that the negative effects of debt level and debt change in the crisis do not necessarily need to translate into negative effects for the economic recovery [13].

Based on these we can claim that the attractiveness of credit resources has defined parameters of relevance. The task of modern scientific research is the evaluation of the characteristics of such parameters and formulation of general propositions regarding the reasonability of attracting credit resources by the economic agents in modern conditions.

\section{Analysis of recent researches and publications}

In Ukrainian and foreign scientific literature attention is paid to the evaluation of the relation between debt and economic growth. Economic growth goes hand in hand with credit deepening (Verner, E. (2019)). That is why many modern scientists pay close attention to studying the effects on economic activity of a pure temporary change in private debt and the relationship between the debt multiplier and the level of economic growth. Herewith the object of the research is the different elements of private debt as well as the general system of its correlations.

S. Hanzdyuk, Y. Vyshnyakova (2019) have concluded that individuals' loans essential differ from the firms' loans to structure, date of issuance and lending purpose [5]. O. Shamanska (2013) has identified stimulant, regulative, and limiting factors, which influence the development of the market of individual loans in Ukraine [16]. V. Horyn (2017) has pointed attention to the fact, that besides essential potential in modern conditions individual loans do not play a particular role in the increase of the prosperity of the society [6]. 
Y. Deryugina and others (2015) have made the complex evaluation of the demand and supply of loans from the position of financial stabilization provision of the country and development of reflexive measures of monetary regulators, relevant to the detected shocks on the market of loans [4].

L. Sun (2018) has found that the leverage indicators do negatively affect the p.c. real GDP growth in China. The ratio of non-financial private debt to GDP has significantly negative impact on China's real p.c. $G D P$ growth, whereas the effects of the ratio of public debt to GDP on the economic growth are insignificant [19].

M. Randveer, L. Uusküla and L. Kulu (2012) have found that a higher level of debt before the recession is correlated with smaller economic growth after the economic slowdown [13].

Gianluca Cafiso (2019) has indicated that household debt has a significant effect on real output, while corporate debt does not seem to exert a systematic influence [3].

A. Schclarek (2005) has considered that in the case of developing countries, lower external debt levels were associated with higher economic growth rates [15]. C. M. Reinhart \& K. S. Rogof (2010) have found that the relationship between public debt and economic growth are the similar among emerging and advanced economies [14].

The evaluation made by scientists with the usage of linear regression models gave the possibility to represent the general characteristics of relation to the specific form of development. For example, V. Horyn (2017) proves that every $1 \%$ of nominal GDP growth in Ukraine causes the increase of debt amount for loans to individuals by $1.5 \%$ [6]. I. Pasinovich, M. Kuchma based on the usage of NBU data and official statistics have concluded the increase of GDP in Ukraine in the case of growth of loans, provided by commercial banks [12]. M. Randveer, L. Uusküla and L. Kulu (2012) have found that for the Estonian economy is typical that 50 percentage point higher debt-to-GDP ratio is associated with a 0.37 percent slower average economic growth. In contrast, higher credit growth before the recession is associated with higher growth after the crisis [13].

Scientists did not limit their researches of the relationship between the debt and economic growth by the using the linear models. They have proved the existence of exponential growth correlation between GDP and private debt. A. Chudik, K. Mohaddes, M. H. Pesaran and M. Raissi (2015) while making the research based on the data of 40 countries (divided on the developed and developing one) for the period 1965-2010 with the help of Monte Carlo method, have proved the existence of essential negative long term effects of government debt increase even in the case of GDP growth [2].

W. G. C. Madhuhansi and A. A. Shantha (2020) have identified the relationship between public debt and economic growth in Sri Lanka [10]. The researches have proved that empirical studies regarding the relationship between external debt and economic growth are showed mixed findings as positive and negative relationships.

M. Lombardi, M. Mohanty, and I. Shim (2017) pointed at the existence of negative results of household debt increase, but assent with the fact, that the increase of the household debt influences the increase of consumption and GDP growth in the short-term period, usually during one year [9].

A. Alter, A. Feng X.n, and N. Valck (2018) confirm that the influence of private debt change on $G D P$ is happening with a particular time lag $(t+n)$ [1]. The period of prolongation the $n$ effect is individual for every economy, as far as depends on the debt structure and sensibility of the production amount and consumption from the credit resources.

\section{Hypothesis formulation and presentation of goals}

In the paper we investigate three main hypotheses. First of all we examine the structure of private debt and it main trends during recent years in Ukraine. Then we explore the households' debt to GDP ratio and firms' debt to GDP ratio. Obtained indicators are useful for proving the hypothesis about the reality of the distinguish country's characteristics in the relations between private debt and GDP. We also determine the time lag of the highest $G D P$ sensitivity to the households' debt movements and firms' debt movements. Finally, we investigate the effects of private debt on economic growth in Ukraine and the reverse effects of economic growth on the private debt expansion. 
The purpose of the article is to determine the effects on economic activity of a pure temporary change in private debt and the relationship between the debt multiplier and the level of economic growth in Ukraine.

\section{Research methods}

This paper used adopted Keynesian growth model according to which, production in period $t$ adjusts to the expected demand. Under this approach, output is demand driven. It is driven by that part of demand which is not induced (proportional to the current output level) but autonomous. Easy credit conditions enhance the autonomy of this part of aggregate demand.

The relation between GDP growth and debt depends on the chosen measure of debt. So in this paper we use the amount of private debt which has measured as households' and firms' debts together. Credit is defined as loans and debt securities financed by domestic and foreign banks, as well as non-bank financial institutions. The level of household and the non-financial firm debt we measure as household debt to GDP ratio $(H H D / Y)$ and non-financial firm debt to $G D P$ ratio $(F D / Y)$ respectively.

Linear regression can be used with relationships that are not inherently linear, but can be made to be linear after a transformation. If to mark the level of private debt by $D_{0}$ the beginning time $(t=0)$, so the speed of the changes in the private debt $\frac{d D(t)}{d t}$ can be defined from the system:

$$
\left\{\begin{array}{l}
\frac{d D(t)}{d t}=k D(t) \\
\left.D(t)\right|_{t=0}=D_{0}
\end{array}\right.
$$

The general solution of equation (1) will be:

$$
D(t)=e^{k t+n}=e^{n} e^{k t} .
$$

We note that an increase in time $t$ of 1 unit results in y being multiplied by $e^{c}$.

As far as we can observe from primary conditions when $=0, D_{0}=e^{n}$, then the equation will be the following:

$$
D(t)=D_{o} e^{k t}
$$

Using Granger approach we determine the direction of relation between private debt and GPD. Rather than testing whether $P D$ causes $G D P$, the Granger causality tests whether $P D$ forecasts $G D P$ (Slav'yuk R., Shkvarcuk L., Kondrat I. (2017) [18]). So we provide the calculation in the direct and indirect methods. The model of the direct method is based on the assumption, that GDP growth in the current period depends on the dynamics of $G D P\left(\Delta_{t-1} Y\right)$ and increase of private debt $\left(\Delta_{t-1} P D\right)$ in the previous period. The equation of the direct correlation is the following (4):

$$
\Delta Y=a_{0}+a_{1} \times \Delta_{t-1} \boldsymbol{Y}+a_{2} \times \Delta_{t-1} P D .
$$

The model of indirect correlation is based on the assumption that the increase of the amounts of private debt $(\triangle P D)$ depends on the former dynamics of $G D P\left(\Delta_{t-1} Y\right)$ and the amount of private debt accumulated in the previous period $\left(\Delta_{t-1} P D\right)$. The equation of indirect form is the following (5):

$$
\Delta P D=b_{0}+b_{1} \times \Delta_{t-1} P D+b_{2} \times \Delta_{t-1} \boldsymbol{Y} .
$$

Data for households and firms debt servicing were obtained from the National Bank of Ukraine. This study used annual time series data from 2002 to 2019.

\section{Presentation of the main material}

Graf 1 shows the changes in the structure of the private debt during 2002-2019 in Ukraine. According to it, the biggest part of the structure of private debt belongs to firms' (non-financial corporations') debt. Its share is near $77 \%$. Such distribution of elements of firms' debt is explained by the bank-centric model of the financial market, which was formed in Ukraine. According to it, the private sector of the economy is financed mostly by bank loans. According to these characteristics, financial market of Ukraine differs from the markets of some developed and developing countries, for which the main part of private debt belongs to the households [7]. 


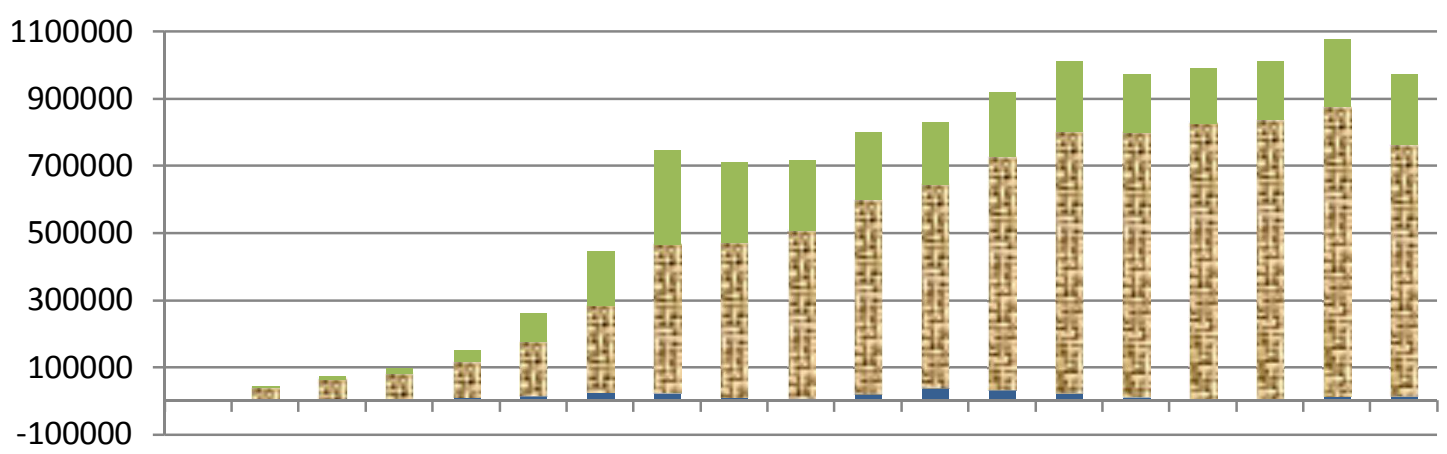

Fig. 1. Structure and trends of private debt in 2002-2019

Source: Generated using Ukraine's National Bank statistics [8]

On average value of the indicator $H H D / Y$ during $2003-2019$ was 0.125 or $12.5 \%$, with the achievement of maximum value 0.283 or $28.30 \%$ in 2008 (Fig. 2). Likewise the average value of $F D / Y$ was 0.367 or $36.7 \%$ with the maximum value 0.506 or $50.60 \%$ in 2014 .

In general in the period 2003-2019 two main peaks of the $P D / Y$ level can be observed: in 2008 and 2014. Despite the general similarity of the tendency in the peak period, it was caused by different factors: in 2008 by the $H H D / Y$ maximum increasing and in 2014 by the achievement of the $F D / Y$ maximum.

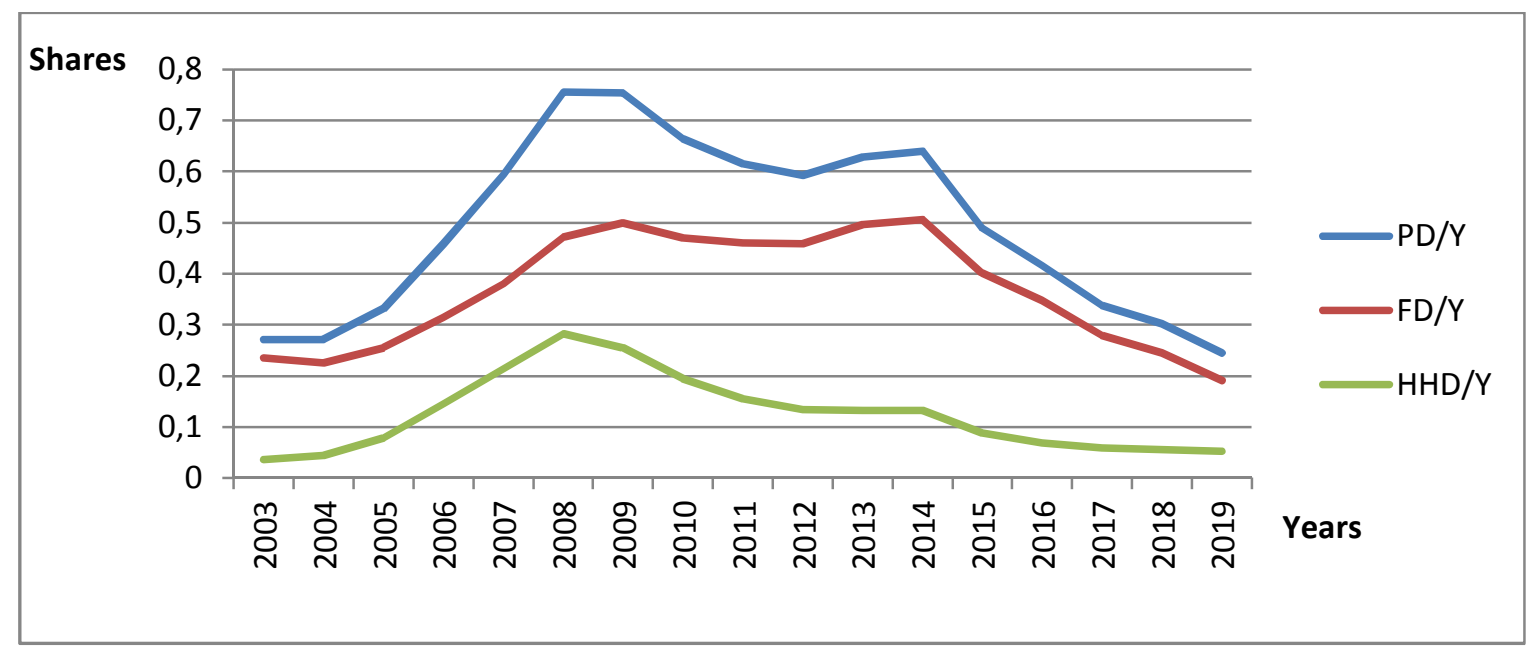

Fig. 2. Trends of private debt and its elements in 2003-2019

Source: Generated using Ukraine's National Bank statistics [8].

The household, firm, and private debt to GPD ratio from year $t-n$ to year $t$ we measure as $\Delta_{n}(H H D / Y)_{t}$ and $\Delta_{n}(F D / Y)_{t}, \Delta_{n}(P D / Y)_{t}$, where $H H D, F D$, and $P D$ are the outstanding levels of loans to households $(H H D)$, non-financial corporations $(F D)$ and private sector $(P D)$, respectively. Table 1 represents the results of the average level of such indicators for Ukraine in 2003-2019.

The received values (Table 1) follow the estimated parameters and the indicators of simultaneous increase of the private debt elements to GDP. We will evaluate the level of the received indicators by comparison with the analogical indicators, calculated by the scientists for the 30 countries (Mian S., \& Verner (2017) [8]). The value of the indicator $\triangle(H H D / Y)$, for the conditions of Ukraine, is very low and 
comparably the same as the level of Mexico (0.20); indicator $\Delta(F D / Y)$ - with the indicator of Japan (0.14), Germany (0.23), Italy (0.52) and USA (0.54). Maximum level the indicator $\Delta(F D / Y)$ was received in 2002-2012 in Ireland (14.11) and Belgium (3.09). E. Verner (2019) presented a similar assumption: countries that are more economically developed have higher private debt-to-GDP ratios.

Table 1

Summary Statistics *

\begin{tabular}{|c|c|c|c|}
\hline & $\Delta\left(\frac{H H D}{Y}\right)$ & $\Delta\left(\frac{F D}{Y}\right)$ & $\Delta\left(\frac{P D}{Y}\right)$ \\
\hline Average & 0.125 & 0.367 & 0.492 \\
\hline Std. dev. & 0.091 & 0.200 & 0.494 \\
\hline
\end{tabular}

* The variables $P D / Y, H H D / Y, F D / Y$ denote log real GDP, private non-financial debt to GDP, household debt to GDP, non-financial firm debt to GDP.

Source: authors' own research.

This gives us the ground to make a hypothesis that there are not close correlation between private debt and economic growth in Ukraine. For proofing it we have made some additional estimation.

The results of lag bias correlation between GDP and private debt for Ukraine in 2003-2019 are placed in Table 2. These demonstrate the GDP sensibility in the period $t+n,(n=(\overline{1 ; 5}))$ to the private debt movements in the period $t_{0}$.

Table 2

\section{Regression estimation*}

\begin{tabular}{|c|c|c|c|c|c|}
\hline & $\Delta_{1} Y$ & $\Delta_{2} Y$ & $\Delta_{3} Y$ & $\Delta_{4} Y$ & $\Delta_{5} Y$ \\
\hline$\triangle F D$ & 0.618897 & 0.445561 & 0.602472 & 0.654273 & 0.570217 \\
\hline$R^{2}$ & 0.383034 & 0.198525 & 0.362973 & 0.258971 & 0.325147 \\
\hline$\triangle H H D$ & 0.618893 & 0.623129 & 0.778565 & 0.809039 & 0.827395 \\
\hline$R^{2}$ & 0.383028 & 0.38829 & 0.606163 & 0.307902 & 0.684582 \\
\hline$\triangle P D$ & 0.641546 & 0.527492 & 0.687883 & 0.735341 & 0.676148 \\
\hline$R^{2}$ & 0.411581 & 0.278248 & 0.473182 & 0.35687 & 0.457177 \\
\hline
\end{tabular}

* Log changes and ratios are multiplied by 100 to report changes in percentages or percent-age points. $\Delta, \Delta_{2}$, $\Delta_{3}, \Delta_{4}, \Delta_{5}$ denote one-year, two-year, three-year, four-year, and five-year changes, respectively.

Source: authors' own research.

According to our calculations (Table 2):

- the highest level of the GDP sensibility to the non-financial corporations' debt $(\triangle F D)$ movements is reaches in the period $\left(t_{1}\right)$;

- the highest level of the GDP sensibility to the household debt $(\triangle H H D)$ movements are reaches in the periods $\left(t_{3}\right)$ and $\left(t_{5}\right)$;

- the highest level of the GDP sensibility to the private debt $(\triangle P D)$ movements are reaches in the periods $\left(t_{3}\right)$ and $\left(t_{5}\right)$.

The obtained results evidence the existence of some time lag of the GDP sensibility to the private debt movement. Such time lag $n$ is different for each elements of private debt, therefore we can't determine it obviously. Moreover, low coefficient of determination $R^{2}$ for $\triangle F D$ and $\triangle P D$ evidences the low reliability of calculation results. The exception is the coefficient of determination $R^{2}$ for the relation between GDP and household debt $(\triangle H H D)$.

After substituting the data for the years 2002-2019 in the formula (4) and (5), we have received the equation: 


$$
\begin{aligned}
\Delta Y & =0.129-0.030 \Delta_{t-1} Y+0.294 \times \Delta_{t-1} P D . \\
\Delta P D & =0.0265+0.705 \times \Delta_{t-1} P D+0.055 \times \Delta_{t-1} Y .
\end{aligned}
$$

Inspection of received relations, based on the usage of main statistical functions, has shown the existence of a relation between the analyzed variables (Table 3).

Table 3

Pilot parameters of Correlation Regressive Analysis over the period 2002-2019

\begin{tabular}{|l|c|c|}
\hline \multicolumn{1}{|c|}{ Indicators } & Equation (6) & Equation (7) \\
\hline Multiple Correlation Coefficient $(R)$ & 0.266492 & 0.674733 \\
\hline Coefficient of Determination $\left(R^{2}\right)$ & 0.071018 & 0.455264 \\
\hline Standard Error & 0.111 & 0.195 \\
\hline$F$-test $(F$-Statistic $)$ & 0.642752 & 0.026 \\
\hline$F_{\text {crit }}(m=2, n=16)$ & \multicolumn{2}{|c|}{3.63} \\
\hline$t$-test $Y$ & 2.161572 & 0.026546 \\
\hline$t$-test $X 1$ & -0.18047 & 0.053509 \\
\hline$t$-test $X 2$ & 0.8579 & 0.70539 \\
\hline$t_{\text {crit }}(m=2, n=16)$ & \multicolumn{2}{|c|}{2.120} \\
\hline
\end{tabular}

Source: authors' own research.

In the case of direct relation (equation (6)), the strength of a linear relationship between variables is weak $\left(R^{2} \leq 0.6\right)$, and in the cases of indirect equation (7) relation density is high $(R>0.6)$. The level of feasibility of presented models, which is defined by the coefficient of determination $\left(R^{2}\right)$ also is different: low - for the models of direct relation equation (6)) and average for the model of indirect relation equation (7)). It gives us reasons to dismiss the model of direct relation as not adequate.

The further conclusions suit only the results of calculation received in the model of indirect relation: changes in the amount of private debt depend on the GDP changes. The GDP growth by $1 \%$ leads to the increase in the private debt by $0.055 \%$. This proves the existence of low investment potential of private debt. The increase in private debt is highly connected with the necessity to attract money for covering current expenses, not the investing one.

Inspection of the model significance, based on the $F$-criterion (Fisher criterion) and $t$-criterion (Student criterion), has proved that there is no linear relation between dependent and independent variables in the model of direct relation as well as in the model of indirect relation $\left(F_{\text {fact }}<F_{\text {crit }}\right)$. Herewith all the chosen variables are significant for the resulting factor $\left(\left|t_{\text {fact }}\right|>t_{\text {crit }}\right)$.

\section{Conclusions}

Conducted research proves our hypothesis that there are some country's characteristics of relations between private debt and GDP. For the conditions of the Ukrainian economy, the strength of such relation is not high, and the stimulant effect is week. In the structure of private debt, the largest part belongs to the non-financial corporations' debt (in medium $77 \%$ in 2002-2019, from which only $2.645 \%$ belongs to debt securities).

The households' debt to GDP ratio $(H H D / Y)$ and non-financial firms' debt to $G D P$ ratio $(F D / Y)$ for the conditions of economy of Ukraine is one of the lowest in Europe, which proves the low attractiveness of debt financing of the private sector growth. The GDP sensibility to the debt movements is reaches at the period $t_{3}$ (the time lag is equal to 3 ). Such conclusion is fair as for the sensitivity to the households' debt movements and so to the firms' debt movements.

Private sector debt cycle more correlated with the business cycles: in the case of GDP growth the private debt rises also. But, the strength of influence of the GDP growth on the private debt growth is temperate: while the increase in the GDP by $1 \%$ in the medium predicts $0.055 \%$ subsequent private debt growth. The coefficient of determination $\left(R^{2}\right)$ for such influence is equal 0.67 which proves the strong correlation between the mentioned indicators. 


\section{Prospects for further research}

The increase in private debt causes the insufficient influence on the GDP increasing, so we cannot consider the debt market growth as a driver of the economy growth in Ukraine. The intensification of credit operations of financial institutions will not lead to rapid and significant growth of Ukraine's economy. This requires the development of research to find alternative tools for economic recovery.

1. Alter A., Feng A. X. N., and Valck N. (2018). Understanding the Macro-Financial Effects of Household Debt: A Global Perspective. IMF Working Paper, 18 (76).

2. Chudik A., Mohaddes K. R., M. Pesaran H., and Raissi M. (2015). Is There a Debt-threshold Effect on Output Growth? IMF Working Paper, 15 (197).

3. Cafiso G. (2019). GDP Growth through Private Debt: The Effect of Monetary Shocks. CESifo Economic Studies, 65(2), pp. 236-253. DOI: 10.1093/cesifo/ify027

4. Deryugina E., Kovalenko O., Pantina I., Ponomarenko A. (2015). Identifikaciia faktorov sprosa i predlogeniia kreditov v Rossii (Identification of supply and demand factors for loans in Russia). Bank of Russia: Economic Research Papers Series, 3.

5. Hanziuk S. and Vyshniakova Yu. (2019). Kredytuvannia cpojyvchuh potreb v Ukraiyni (Lending consumer needs in Ukraine). Investytsiyi: praktyka ta dosvid, 18, pp. 47-52. DOI: 10.32702/2306-6814.2019.18.47).

6. Horyn V. P. (2017). Rol kredytuvannia domohospodarstv u pidvyschenni dobrobutu v Ukraiyni (The role of household lending in improving public welfare in Ukraine). Science and economics, 1 (45).

7. Kim Yun K. (2016). Macroeconomic effects of household debt: an empirical analysis. Review of Keynesian Economics, 4 (2), pp. 127-150.

8. Kredyty, nadani deposytnymy korporaciiamy (krim Nacionalnoho Banku Ukraiiny) (Loans granted by deposit-taking corporations (excluding National bank of Ukraine)). Report of National Bank of Ukraine (2020). Retrieved from: https://bank.gov.ua/en/statistic/sector-financial/data-sector-financial.

9. Lombardi M., Mohanty M. and Shim I. (2017). The real effects of household debt in the short and long run. BIS Working Papers, 607, p. 42.

10. Madhuhansi W. G. C., and Shantha A. A. (2020). The Effects of Public Debt on Economic Growth in Sri Lanka. Sri Lanka Journal of Social Sciences and Humanities, 1(1), pp. 33-41.

11. Mian S., and Verner (2017). Household Debt and Business Cycles Worldwide. Quarterly Journal of Economics, 132 (4), pp. 1755-1817.

12. Pasinovych I. I., and Kuchma M. I. (2018). Neobhidnist ta umovy vidnovlennia kredytuvannia dlia zabezpechennia ekonomichnogo zrostannia v Ukraiyni (Necessity and conditions of crediting return for ensuring economic growth in Ukraine). Scientific Bulletin of Uzhhorod National University. Series: International Economic Relations and the World Economy, 20 (2), pp. 161-165.

13. Randveer M., Uuskula L., \& Kulu L. (2012). The impact of private debt on economic growth. Bank of Estonia Working Papers, 10.

14. Reinhart C. M., \& Rogof K. S. (2010). Growth in a time of debt. American Economic Review, 1, pp. 573-578.

15. Schclarek A. (2005). Debt and Economic Growth in Developing and Industrial Countries. Working Papers of Lund University, Department of Economics, 34.

16. Shamanska O. (2013). Suchasni motyvy ta tendenciiy realizaciiy kredytnoiy povedinky domohospodarstv v Ukraiyni (Current motives and trends in the implementation of credit behavior by households in Ukraine). Scientific Notes of Ostroh National Academy. Economy, 22, pp. 94-96.

17. Silva J. (2020). Impact of public and private sector external debt on economic growth: the case of Portugal. Eurasian Economic Revue, 10, pp. 607-634. DOI: 10.1007/s40822-020-00153-2.

18. Slav'yuk R., Shkvarcuk L., Kondrat I. (2017). Financial market imbalance: reasons and peculiarities of occurrence in Ukraine. Investment Management and Financial Innovations, 14 (1), pp. 227-235.

19. Sun L. (2018). Quantifying the Effects of Financialization and Leverage in China. Chinese Economy. 51 (1), pp. 1-18. DOI: 10.1080/10971475.2017.1398363.

20. Verner E. (2019). Private Debt Booms and the Real Economy: Do the Benefits Outweigh the Costs? Retrieved from: https://ssrn.com/abstract=3441608 or http://dx.doi.org/10.2139/ssrn.3441608.

1. Alter A., Feng A. X.n, and Valck N. (2018). Understanding the Macro-Financial Effects of Household Debt: A Global Perspective. IMF Working Paper, No.18/76, 49 p.

2. Chudik A., Mohaddes K.r, M. Pesaran H., and Raissi M. (2015). Is There a Debt-threshold Effect on Output Growth? IMF Working Paper, No. 15/197.

3. Cafiso G. (2019). GDP Growth through Private Debt: The Effect of Monetary Shocks. CESifo Economic Studies, 65(2), 236-253. DOI: 10.1093/cesifo/ify027. 
4. Дерюгина Е., Коваленко О., Пантина И., Пономаренко А. (2015). Идентификация факторов спроса и предложения кредитов в России. Банк России: Серия докладов об экономических исследованиях, № 3,38 с.

5. Ганзюк С. М., Вишнякова Ю. О. (2019). Кредитування споживчих потреб в Україні. Інвестиції: практика та досвід, № 18, C. 47-52. DOI: 10.32702/2306-6814.2019.18.47

6. Горин В. П. (2017). Роль кредитування домогосподарств у підвищенні суспільного добробуту в Україні. Наука й економіка, № 1 (45).

7. Kim Yun K. (2016). Macroeconomic effects of household debt: an empirical analysis. Review of Keynesian Economics, Vol. 4, No. 2, pp. 127-150.

8. Кредити, надані депозитними корпораціями (крім Національного банку Украӥни). Звіт Національного Банку України (2020). Available at: https://bank.gov.ua/en/statistic/sector-financial/data-sector-financial

9. Lombardi M., Mohanty M. and Shim I. (2017). The real effects of household debt in the short and long run. BIS Working Papers, 607, p. 42.

10. Madhuhansi W. G. C., and Shantha A. A. (2020). The Effects of Public Debt on Economic Growth in Sri Lanka. Sri Lanka Journal of Social Sciences and Humanities, 1(1), pp. 33-41.

11. Mian S., and Verner (2017). Household Debt and Business Cycles Worldwide. Quarterly Journal of Economics, 132 (4), pp. 1755-1817.

12. Пасінович I. I., Кучма М. І. (2018). Необхідність та умови відновлення кредитування для забезпечення економічного зростання в Україні. Науковий вісник Ужгородського національного університету. Серія: Міжнародні економічні відносини та світове господарство, Вип. 20, ч. 2, С. 161-165.

13. Randveer M., Uuskula L., \& Kulu L. (2012). The impact of private debt on economic growth. Bank of Estonia Working Papers, 10.

14. Reinhart C. M., \& Rogof K. S. (2010). Growth in a time of debt. American Economic Review, 1, pp. 573-578.

15. Schclarek A. (2005). Debt and Economic Growth in Developing and Industrial Countries. Working Papers of Lund University, Department of Economics, 34.

16. Шаманська О. С. (2013). Сучасні мотиви та тенденції реалізації кредитної поведінки домогосподарствами в Україні. Наукові записки Наџіонального університету “Острозька академія”. Економіка, 22, С. 94-96.

17. Silva J. (2020). Impact of public and private sector external debt on economic growth: the case of Portugal. Eurasian Economic Revue, 10, pp. 607-634. DOI: 10.1007/s40822-020-00153-2

18. Slav'yuk R., Shkvarcuk L., Kondrat I. (2017). Financial market imbalance: reasons and peculiarities of occurrence in Ukraine. Investment Management and Financial Innovations, 14 (1), pp. 227-235.

19. Sun L. (2018). Quantifying the Effects of Financialization and Leverage in China. Chinese Economy, 51 (1), 1-18. DOI: 10.1080/10971475.2017.1398363.

20. Verner E. (2019). Private Debt Booms and the Real Economy: Do the Benefits Outweigh the Costs? Retrieved from: http://dx.doi.org/10.2139/ssrn.3441608

$$
\begin{array}{r}
\text { Л. О. Шкварчук }{ }^{1} \text { Р. А. Слав’юк } \\
\text { Національний університет “Львівська політехніка”, } \\
{ }^{1} \text { кафедра фінансів, } \\
{ }^{2} \text { кафедра підприємництва та екологічної експертизи товарів } \\
\text { ORCID: }{ }^{1} 0000-0001-7241-3961,{ }^{2} 0000-0002-0904-8970
\end{array}
$$

\section{ПРИВАТНИЙ БОРГ ТА ЕКОНОМІЧНЕ ЗРОСТАННЯ: ТРЕНДИ ТА ХАРАКТЕРИСТИКИ В УКРАЇНІ}

(С Шкварчук Л. О., Слав'юк Р. А., 2021

Досліджено взасмозалежності темпів зростання ВВП України та приватного боргу. На основі застосування функції експоненціального росту розраховано лагову чутливість темпів змін ВВП та приватного боргу. Оцінено чутливість ВВП країни до змін у величині та динаміці приватного боргу. Використання підходу Грейнджера дало можливість оцінити приріст обсягів приватного боргу порівняно із попередньою динамікою ВВП та обсяг нарощеного у попередньому періоді приватного боргу за моделлю прямого та зворотного зв'язку.

Ключові слова: приватний борг; відношення боргу домогосподарств до ВВП; відношення боргу нефінансових корпорацій до ВВП; економічне зростання; чутливість ВВП до зміни боргу. 